\title{
Elevated Levels of Osmoprotectants Securing Sugarcane (Saccharum officinarum L.) during Salinity Stress
}

\author{
C. L. Pote ${ }^{1}$, P. S. Chougule ${ }^{1 *}$, A. A. Kale ${ }^{2}$, D. V. Shirsat ${ }^{2}$, R. M. Naik ${ }^{1}$, A. S. Jadhav ${ }^{2}$, \\ R. M. Garkar ${ }^{3}$ and C. A. Nimbalkar ${ }^{4}$ \\ ${ }^{1}$ Department of Biochemistry, Post Graduate Institute, ${ }^{2}$ State Level Biotechnology Center, \\ Mahatma Phule Krishi Vidyapeeth, Rahuri, Maharashtra, India \\ ${ }^{3}$ Central Sugarcane Research Station, Padegoan, Dist. Satara, Maharashtra, India \\ ${ }^{4}$ Department of Statistics, Post Graduate Institute, Mahatma Phule Krishi Vidyapeeth, Rahuri, \\ Maharashtra, India \\ *Corresponding author
}

\section{A B S T R A C T}

Keywords

Osmoprotectant, Glycine beaten, Proline, Salinity stress

Article Info

Accepted:

12 November 2019

Available Online:

10 December 2019
Sugarcane is (Saccharum officinarum L.) is one of the most important commercial crops of the world, including region where water availability is limited or highly inconsistent. Abiotic stresses may decline in potential yield of crop plants by $70 \%$. In sugarcane numerous environmental factors can have negative effects on the increase in expansion of production and salinity stress is one of the most limiting abiotic factors affecting sugarcane productivity. Two sugarcane varieties viz., MS10001 and CoC671 were sown in the pots and were evaluated for the levels of the osmoprotectants, proline, glycine betaine, and sugars i.e., reducing, non-reducing and total sugar under different salt stress levels of sodium chloride $\left(0,2,4,8 \mathrm{dSm}^{-1}\right)$.

\section{Introduction}

Sugarcane (Saccharum sp.) has great economic importance due to its application in the food industry and is also particularly valuable for its use in the production of ethanol and a less polluting renewable bio fuel (Menossi et al., 2008). Originating in Asia, sugarcane is highly productive in the tropical and sub-tropical areas of the world. However, the adverse environmental conditions affect the growth and development of sugarcane plants (Lisson et al., 2005 and Inman Bamber and Smith, 2005). High salt concentrations decrease the osmotic potential of soil solution creating a water stress in plants and also cause 
severe ion toxicity, saline $\mathrm{Na}^{+}$is not readily sequestered into vacuoles as in halophytes. Salt stress consists of two components, like, osmotic stress caused by the increase in external osmotic pressure due to high external concentration of salt and the physiological and biochemical effect of cations and anions on plant cell (Munns and Termaat, 1986).

In India, area under sugarcane cultivation increased substantially from $1.71 \mathrm{mha}$ in 1950 51 to 5.35mha in 2013-14. The major sugarcane growing states are Uttar Pradesh, Maharashtra, Karnataka, Tamilnadu, Andhra Pradesh and Gujarat. These six states together accounted for about 85.42 per cent of India's total area in 2013- 14. Maharashtra is the largest producer of sugar contributes about 34 $\%$ of sugar in the country followed by Uttar Pradesh. In Maharashtra, sugarcane was grown on around 1million hectare in 2015-16. In the current season, acreage under sugarcane has shrunk to 7,80,000 hectares and ISMA estimates that Maharashtra's sugar yield in 2016-17 will be around 6.1 million tons as against 8.4 million tons in 2015-16. In a majority of higher plant halophytes examined, proline is the major component of the amino acid pool in plants collected from the field. Glycine betaine, a quaternary ammonium compound, is another predominant osmoprotectant. The responses of transgenic plants to stress demonstrated that genetic engineering of the synthesis of glycine betaine increased the ability of the plants to tolerate a variety of environmental stresses (Sakamoto and Murata, 2002).

\section{Materials and Methods}

\section{Planting material and stress treatment}

The planting material of two sugarcane cultivars, MS-10001 a salinity tolerant and CoC-671 a salinity sensitive were obtained from Central Sugarcane Research Station,
Padegaon, Dist. Satara. The sets were planted in a plastic pots containing black soil in three replicates for each treatment and grown in the control conditions in green house. After 60 days after planting the stress treatment was imposed with $\mathrm{NaCl}$ solution of concentration $0,2,4,8 \mathrm{dSm}^{-1}$.

\section{Estimation of proline}

Proline content in leaf tissues of both stressed and control plant leaves of sugarcane was determined by using the acid ninhydrin reagent as per the method described by Bates et al., (1973). Leaf samples (0.2 g) were homogenized with $2 \mathrm{ml}$ of sulphosalicylic acid and the homogenate was filtered through Whatman No. 2 filter paper. A suitable volume of the filtrate was reacted with $2 \mathrm{ml}$ of acid ninhydrin and $2 \mathrm{ml}$ of glacial acetic acid in a test tube for $1 \mathrm{hr}$. at $1000 \mathrm{C}$ and the reaction was terminated by placing the tubes in ice. The reaction mixture was extracted with $4 \mathrm{ml}$ toluene and mixed vigorously for 15 to 20 seconds. The chromophore containing toluene was aspirated from the aqueous phase and the absorbance read at $520 \mathrm{~nm}$ using toluene as a blank. The proline concentration was determined from the standard curve prepared from different concentrations of proline and calculated on a fresh weight basis. The proline content was expressed as umoles $\mathrm{g}^{-1}$ fresh weight.

\section{Estimation of glycine betaine}

Glycine betaine content in leaves of both the unstressed and stressed seedlings of sugarcane was determined by using the Dragendorff reagent as per the method described by Stumpf (1984). Leaf sample, $0.2 \mathrm{~g}$ was crushed in a mortar and pestle in $2 \mathrm{ml}$ of $80 \%$ $(\mathrm{v} / \mathrm{v})$ ethanol. It was transferred into the eppendorf tubes which were kept in the hot water bath for $20 \mathrm{~min}$. The tubes were then removed from water bath and cooled at room 
temperature. It was centrifuged at $10,000 \mathrm{xg}$ for $20 \mathrm{~min}$ and the supernatant was collected in clean eppendorf tubes. The supernatant $(0.2$ $\mathrm{ml}$ ) was pipetted in the microfuge tubes to which $100 \mu$ Dragendroff reagent was added.

The solution was then centrifuged at $7000 \mathrm{xg}$ for one min. After centrifugation, the supernatant was removed with the help of a syringe and the orange pellet was dried. The pellet was dissolved in $1 \mathrm{ml}$ solution of 2.45 $\mathrm{M}$ NaI. From this $200 \mu \mathrm{l}$ aliquot was pipetted in test tubes containing $3 \mathrm{ml}$ diluted $0.49 \mathrm{M}$ $\mathrm{NaI}$ solution and mixed. The absorbance was read at $467 \mathrm{~nm}$ using $0.49 \mathrm{M} \mathrm{NaI}$ solution as a blank. The standard curve prepared from the standard curve prepared from the betaine aldehyde. The glycine betaine content was expressed as umoles $\mathrm{g}^{-1}$ fresh weight.

\section{Estimation of reducing sugars}

Reducing sugars were determined by NelsonSomogyi method (Nelson, 1944). Defatted sample was finely ground in mortar and pestle and $0.5 \mathrm{~g}$ was extracted with $80 \%$ boiling ethanol. The supernatant obtained after centrifugation at $8000 \mathrm{rpm}$ for $10 \mathrm{~min}$. was collected and extraction was repeated twice. The combined ethanolic extract was then evaporated to about 8 to $10 \mathrm{ml}$ and then diluted to $50 \mathrm{ml}$ with distilled water. The extract was used for the determination of sugars.

The $0.2 \mathrm{ml}$ of sugar extract and $0.8 \mathrm{ml}$ of distilled water, one $\mathrm{ml}$ of copper reagent was added. The content were mixed and heated for 20 min. in boiling water bath. The tubes were cooled. One $\mathrm{ml}$ of arsenomolybdate reagent was added and mixed well. This mixture was diluted with $7 \mathrm{ml}$ of distilled water and the absorbance was taken at $520 \mathrm{~nm}$ against blank. The reducing were calculated from a standard curve for D-glucose and expressed as milligrams per $100 \mathrm{~g}$ dry weight.

\section{Estimation of Total Sugar}

To the $25 \mathrm{ml}$ of ethanolic extract $2.5 \mathrm{ml}$ of sulphuric acid was added and kept for 24 hours for inversion. It was neutralized with sodium hydroxide using $\mathrm{pH}$ meter and the volume was made to $50 \mathrm{ml}$. The hydrolyzed sugars were estimated as reducing sugars by Nelson-Somogyi method (Nelson, 1944). Non-reducing sugar content was calculated as difference between total and reducing sugars.

\section{Results and Discussion}

The proline content of control and salt stressed of two sugarcane varieties are shown in Table 1. The stressed leaves showed increase in proline content with increase in imposed salt stress over unstressed control of two sugarcane varieties. The proline contain in a salinity tolerant sugarcane variety MS10001 was 0.73 umoles g- 1 fresh weight (FW). at 0 $\mathrm{dSm}^{-1}$ (control), 1.15 umoles $\mathrm{g}-1 \mathrm{FW}$ at 2 $\mathrm{dSm}^{-1}, 1.59$ umoles $\mathrm{g}^{-1} \mathrm{FW}$ at $4 \mathrm{dSm}^{-1}, 1.82$ umoles $\mathrm{g}^{-1} \mathrm{FW}$ at $8 \mathrm{dS} \mathrm{m}^{-1}$, whereas in $\mathrm{CoC}$ 671 it was 0.45 umoles $\mathrm{g}^{-1} \mathrm{FW}$ at $0 \mathrm{dSm}^{-1}$ (control), 1.11 umoles $\mathrm{g}^{-1} \mathrm{FW}$ at $2 \mathrm{dSm}^{-1}, 1.42$ umoles $\mathrm{g}^{-1} \mathrm{FW}$ at $4 \mathrm{dSm}^{-1}, 1.53$ umoles $\mathrm{g}^{-1} \mathrm{FW}$ at $8 \mathrm{dSm}^{-1}$.

The increase in proline content may function in cells to lower or balance the osmotic potential of intercellular and extracellular ions to tolerate osmotic stresses. Earlier it was reported that accumulation of osmolyte like proline is known to occur under osmotic stress (Hasegawa et al., 2000; Garg et al., 2002; Munns, 2005). The levels of free proline, an important osmolyte and free radical scavenger increased substantially in salt tolerant (CoM0265) and salt susceptible (CoC-671) sugarcane varieties due to salinity (Satbhai et al., 2014). It was further noticed that the under unstressed (control) condition the level of proline was 0.486 in CoM-265 and it increased to $1.844 \mathrm{umol} \mathrm{g}^{-1} \mathrm{FW}$ an increase of $279 \%$ over control. The level of free proline 
increased from 0.657 to $1.651 \mathrm{ulmol} \mathrm{g}^{-1} \mathrm{FW}$ in CoC-671 an increase of $151 \%$ over control. Saxena et al., (2010) reported that the nitrogenous constituents like proline showed increasing trend in all the sugarcane varieties grown under saline soil condition as compared to normal at formative stage of the crop. Patade et al., (2011) reported that the salt and PEG stressed plants accumulated more than four-fold free proline as compared to the control.

The glycine betaine content of control and salt stressed plant of two sugarcane varieties are presented in Table 2. The stressed leaves showed increase in glycine betaine content over unstressed control in two sugarcane varieties. However, increase was significantly more in salt tolerant MS-10001 variety than salt susceptible CoC-671 variety. Glycine betaine in Sugarcane variety MS-10001 was 2.22 umoles g $^{-1} \mathrm{FW}$ at $0 \mathrm{dSm}^{-1}$ (control), 3.04 umoles $\mathrm{g}^{-1} \mathrm{FW}$ at $2 \mathrm{dSm}^{-1}, 3.87$ umoles $\mathrm{g}^{-1} \mathrm{FW}$ at $4 \mathrm{dSm}^{-1}, 5.87$ umoles $\mathrm{g}^{-1} \mathrm{FW}$ at $8 \mathrm{dSm}^{-1}$, whereas, in $\mathrm{CoC} 671$ it was 1.79 umoles $^{-1}$
FW at $0 \mathrm{dSm}^{-1}$ (control), 3 umoles $\mathrm{g}^{-1} \mathrm{FW}$ at 2 $\mathrm{dSm}^{-1}, 3.72$ umoles $\mathrm{g}^{-1} \mathrm{FW}$ at $4 \mathrm{dSm}^{-1}, 5.31$ umoles $\mathrm{g}^{-1} \mathrm{FW}$ at $8 \mathrm{dSm}^{-1}$.

Satbhai et al., (2014) reported that in salt tolerant (CoM-265) and salt susceptible (CoC671) varieties of sugarcane, the levels of glycine-betaine were increased significantly due to salt stress. In CoM 265 the level increased from 28.23 to $173.6 \mathrm{ug} \mathrm{g}^{-1} \mathrm{FW}$, an increase of $515 \%$, as against with an increase of $51 \%$ in CoC-671, a salt susceptible variety. Patade et al., (2011) reported that the the glycine betaine accumulation was more in salt (by $23 \%$ ) and PEG (by $16 \%$ ) stressed plants as compared to the control plants. Some of the osmolytes that accumulate in plant cells in response to stress also play a role in scavenging of free radicals and protecting enzymes (Sharma and Dubey, 2005). Accumulation of osmolyte like glycine betaine is known to occur under osmotic stress (Hasegawa et al., 2000; Garg et al., 2002; Munns 2005).

Table.1 Effect of induced salinity stress on proline and glycine betaine in salinity tolerant and salinity susceptible sugarcane varieties

\begin{tabular}{|c|c|c|c|c|c|c|c|c|c|}
\hline \multirow{3}{*}{$\begin{array}{l}\text { Sr. } \\
\text { No. }\end{array}$} & \multirow[t]{3}{*}{ Varieties } & \multicolumn{4}{|c|}{ Proline ( $\mu$ moles $\mathrm{g}^{-1}$ fr. wt.) } & \multicolumn{4}{|c|}{ Glycine betaine ( $\mu$ moles $\mathrm{g}^{-1}$ fr. $\left.w t.\right)$} \\
\hline & & \multicolumn{8}{|c|}{ Stress Level $\left(\mathrm{dS} \mathrm{m}^{-1}\right)$} \\
\hline & & $\mathbf{0}$ & 2 & 4 & 8 & $\mathbf{0}$ & 2 & 4 & 8 \\
\hline & \multicolumn{9}{|c|}{ Salinity Tolerant Variety } \\
\hline \multirow[t]{2}{*}{1.} & MS10001 & $\begin{array}{c}0.73 \\
(0)\end{array}$ & $\begin{array}{c}1.15 \\
(57.53)\end{array}$ & $\begin{array}{c}1.59 \\
(117.81)\end{array}$ & $\begin{array}{c}1.82 \\
(149.32)\end{array}$ & $\begin{array}{c}2.22 \\
(0)\end{array}$ & $\begin{array}{c}3.04 \\
(36.94)\end{array}$ & $\begin{array}{c}3.87 \\
(74.32)\end{array}$ & $\begin{array}{c}5.87 \\
(164.41)\end{array}$ \\
\hline & \multicolumn{9}{|c|}{ Salinity Susceptible Variety } \\
\hline 2. & CoC671 & $\begin{array}{c}0.45 \\
(0)\end{array}$ & $\begin{array}{c}1.11 \\
(146.67)\end{array}$ & $\begin{array}{c}1.42 \\
(215.56)\end{array}$ & $\begin{array}{c}1.53 \\
(240.00)\end{array}$ & $\begin{array}{c}1.79 \\
(0)\end{array}$ & $\begin{array}{c}3 \\
(67.60)\end{array}$ & $\begin{array}{c}3.72 \\
(107.82)\end{array}$ & $\begin{array}{c}5.31 \\
(196.65)\end{array}$ \\
\hline & \multicolumn{9}{|c|}{ Interaction between varieties and treatment } \\
\hline & Comparison & \multirow{2}{*}{\multicolumn{2}{|c|}{0.016}} & \multirow{2}{*}{\multicolumn{2}{|c|}{$\mathrm{CD}$ at $5 \%$}} & \multicolumn{2}{|c|}{ S.E. \pm} & \multicolumn{2}{|c|}{ CD at $5 \%$} \\
\hline & Variety & & & & & \multirow{2}{*}{\multicolumn{2}{|c|}{$\begin{array}{l}0.033 \\
0.046\end{array}$}} & \multirow{2}{*}{\multicolumn{2}{|c|}{0.101}} \\
\hline & Treatments & \multicolumn{2}{|c|}{0.023} & \multicolumn{2}{|c|}{0.070} & & & & \\
\hline & $\begin{array}{c}\text { Variety } x \\
\text { Treatment }\end{array}$ & \multicolumn{2}{|c|}{0.032} & \multicolumn{2}{|c|}{0.099} & \multicolumn{2}{|c|}{0.066} & \multicolumn{2}{|c|}{0.202} \\
\hline
\end{tabular}

*Values in parenthesis indicates \% increase over control 
Table.2 Effect of induced salinity stress on reducing sugar, non reducing sugar and total sugar in salinity tolerant and salinity susceptible sugarcane varieties

\begin{tabular}{|c|c|c|c|c|c|c|c|c|c|c|c|c|c|}
\hline \multirow{3}{*}{$\begin{array}{l}\text { Sr. } \\
\text { No. }\end{array}$} & \multirow[t]{3}{*}{ Varieties } & \multicolumn{4}{|c|}{ Reducing sugar (mg g $\left.{ }^{-1} \mathrm{DW}\right)$} & \multicolumn{4}{|c|}{ Non reducing sugar $\left(\mathrm{mg} \mathrm{g}^{-1} \mathrm{DW}\right)$} & \multicolumn{4}{|c|}{ Total sugar (mg g $\left.{ }^{-1} \mathrm{DW}\right)$} \\
\hline & & \multicolumn{12}{|c|}{ Stress Level $\left(\mathrm{dS} \mathrm{m}^{-1}\right)$} \\
\hline & & $\mathbf{0}$ & 2 & 4 & 8 & $\mathbf{0}$ & 2 & 4 & 8 & $\mathbf{0}$ & 2 & 4 & 8 \\
\hline & \multicolumn{13}{|c|}{ Salinity Tolerant Variety } \\
\hline \multirow[t]{2}{*}{1.} & MS10001 & $\begin{array}{l}1.87 \\
(0)\end{array}$ & $\begin{array}{c}3.06 \\
(63.64)\end{array}$ & $\begin{array}{c}4.55 \\
(143.32)\end{array}$ & $\begin{array}{c}5.54 \\
(196.26)\end{array}$ & $\begin{array}{l}1.81 \\
(0)\end{array}$ & $\begin{array}{c}2.75 \\
(51.93)\end{array}$ & $\begin{array}{c}4.64 \\
(156.53)\end{array}$ & $\begin{array}{c}5.15 \\
(184.53)\end{array}$ & $\begin{array}{c}3.72 \\
(0)\end{array}$ & $\begin{array}{c}5.66 \\
(52.15)\end{array}$ & $\begin{array}{c}9.24 \\
(148.39)\end{array}$ & $\begin{array}{c}10.64 \\
(186.02)\end{array}$ \\
\hline & \multicolumn{13}{|c|}{ Salinity Susceptible Variety } \\
\hline \multirow[t]{6}{*}{2.} & CoC671 & $\begin{array}{l}1.70 \\
(0)\end{array}$ & $\begin{array}{c}2.66 \\
(56.47)\end{array}$ & $\begin{array}{c}3.42 \\
(101.18)\end{array}$ & $\begin{array}{c}5.54 \\
(225.88)\end{array}$ & $\begin{array}{l}1.72 \\
(0)\end{array}$ & $\begin{array}{c}1.82 \\
(5.81)\end{array}$ & $\begin{array}{c}2.80 \\
(67.79)\end{array}$ & $\begin{array}{c}3.63 \\
(111.05)\end{array}$ & $\begin{array}{c}3.41 \\
(0)\end{array}$ & $\begin{array}{c}4.31 \\
(26.39)\end{array}$ & $\begin{array}{c}7.23 \\
(112.02)\end{array}$ & $\begin{array}{c}9.11 \\
(167.16)\end{array}$ \\
\hline & \multicolumn{13}{|c|}{ Interaction between varieties and treatment } \\
\hline & Comparison & & E. \pm & $\mathrm{CD}$ a & $5 \%$ & & E. \pm & $\mathrm{CD} \mathrm{a}$ & $5 \%$ & & E. \pm & CD a & $5 \%$ \\
\hline & Variety & & 036 & 0.1 & & & 035 & 0.0 & & & 051 & 0.1 & 56 \\
\hline & Treatments & & 051 & 0.1 & & & 050 & 0.0 & & & 072 & 0.2 & 21 \\
\hline & $\begin{array}{l}\text { Variety x } \\
\text { Treatment }\end{array}$ & & 072 & 0.2 & & & 070 & 0.0 & & & 101 & 0.3 & 12 \\
\hline
\end{tabular}

*Values in parenthesis indicates \% increase over control 
Quarternary ammonium compounds like glycine betaine and other low molecular weight metabolites serve a function in cells to lower or balance the osmotic potential of intercellular and extracellular ions to tolerate osmotic stresses. Organic solutes known as compatible solutes like sugars, serve a function in cells to lower or balance the osmotic potential of intercellular and extracellular ions to tolerate osmotic stresses. Patade et al., (2011) reported that the PEG stressed plants accumulated significantly more total soluble and reducing sugars as compared to the salt stressed and control plants. Pagariya et al., (2012) stated that the increase in organic solutes (sucrose, glucose and fructose) maintains the plant osmotic potential during severe stress condition. As expected the changes in reducing sugars followed increase during both germination and tillering stages. At germination stage, salt treated plants showed $65 \%(1 \% \mathrm{NaCl})$ and $88 \%(2 \% \mathrm{NaCl})$ increase in sugar content compared to control after 30 DAP, while drastically decreased during recovery phase. At tillering stage, a progressive 2.7 folds increase was seen in $3 \%$ $\mathrm{NaCl}$ treated plants compared to respective 1 DAT plants. Contrastingly a sudden $57 \%$ decrease was seen at 10 DAR when plants translocated to normal soil for revitalization from $3 \% \mathrm{NaCl}$ treatments although a steady increase was observed in $2 \% \mathrm{NaCl}$ treated plants compared to respective stressed plants. Similar trend was observed in the present investigation.

\section{References}

Bates, L.S., Waldren, R.P. and Teare, I.D. 1973. Rapid determination of free proline for water stress studies. Plant and Soil. 39: 205-207.

Garg, A.K., Kim, J.K., Owens, T.G., Ranwala, A.P., Choi, Y.D., Kochian, L.V. and $\mathrm{Wu}$, R.J. 2002. Trehalose accumulation in rice plants confers high tolerance levels to different abiotic stresses. Proc. Natl. Acad. Sci. 99: 15898-15903.

Hasegawa, P.M., Bressan, R.A., Zhu, J.K. and Bohnert, H.J. 2000. Plant cellular and molecular responses to high salinity. Annu. Rev. Plant Mol. Biol. 51: 463499.

Inman-Bamber, N.G. and Smith, D.M. 2005. Water relations in sugarcane and response to waters deficits. Field Crops Res. 92: 185-202.

Lisson, S.N., Inman-Bamber, N.G., Robertson, M.J. and Keating, B.A. 2005. The historical and future contribution of crop physiology and modeling research to sugarcane production systems. Field Crops Res. 92: 321-335.

Menossi, M., Siva-Filho, M.C., Vinentz, M., Van-Sluys, M.A. and Souza, G.M. 2008. Sugarcane functional genomics: Gene discovery for agronomic trait development. Int. J. Plant Genomics. 1-11.

Mundree, S.G., Baker, B., Mowla, S., Peters, S., Marais, S., Wilingen, C.V., Govender, K., Maredza, A., Muyanga, S., Farrant, J. M. and Thomson, J. A. 2002. Physiological and molecular insights into drought tolerance. Afr. J. Biotechnol. 1: 28-38.

Munns, R. and Termaat, A. 1986. Whole plant response to salinity. Aust. J. Pl. Physiol. 13: 143-160.

Munns, R. 2005. Genes and salt tolerance : bringing them together. New Phytol. 167: 645-663.

Nelson, N. 1944. A photometric adaptation of the Somogyi method for the determination of glucose. J. Biol. Chem. 15: 375-380.

Pagariyaa, M.C., Devarumatha, R.M. and Kawara, P.G. 2012. Biochemical characterization and identification of differentially expressed candidate 
genes in salt stressed sugarcane. Plant Sci. 184: 1-13.

Patade, V.Y., Bhargava, S. and Suprasanna, P. 2011. Salt and drought tolerance of sugarcane under iso-osmotic salt and water stress: growth, osmolytes accumulation and antioxidant defense. J. Plant Interactions. 6(4): 275-282.

Sakamoto, A. and Murata, N. 2002. The role of glycine betaine in the protection of plants from stress: Clues from transgenic plants. Plant Cell Environ. 25: $163-171$.

Satbhai, R.D. and Naik, R.M. 2014. Osmolytes accumulation, cell membrane integrity, and antioxidant enzymes in sugarcane varieties differing in salinity tolerance. Sugar Tech. 16(1): 30-35.

Saxena, P., Srivastava, R.P. and Sharma, M.L. 2010. Studies on salinity stress tolerance in sugarcane varieties. Sugar Tech. 12(1): 59-63.

Sharma, P. and Dubey, R.S. 2005. Drought induces oxidative stress and enhances the activities of antioxidant enzymes in growing rice seedlings. Plant Growth Regul. 46: 209-221.

Stumpf, D.K. 1984. Quantitation and purification of quarternary ammonium compounds from halophyte tissue. Plant Physiol. 75: 273-274.

\section{How to cite this article:}

Pote, C. L., P. S. Chougule, A. A. Kale, D. V. Shirsat, R. M. Naik, A. S. Jadhav, R. M. Garkar and Nimbalkar, C. A. 2019. Elevated Levels of Osmoprotectants Securing Sugarcane (Saccharum officinarum L.) during Salinity Stress. Int.J.Curr.Microbiol.App.Sci. 8(12): 14821488. doi: https://doi.org/10.20546/ijcmas.2019.812.177 